\title{
Feasibility Study for Dredging of Khaprabhanga Chapalir Don River in Patuakhali District for Improvement of Navigability
}

\author{
Mohammad Ziaur Rahman ${ }^{1 *}$, Shume Akhter ${ }^{2}$, Md. Saiful Islam ${ }^{3}$, \\ Zahirul Haque Khan ${ }^{4}$ \\ ${ }^{1}$ Junior Specialist, Coast Port and Estuary Management Division, Institute of Water Modelling, Bangladesh \\ ${ }^{2}$ Associate Specialist, Coast Port and Estuary Management Division, Institute of Water Modelling, Bangladesh \\ ${ }^{3}$ Junior Engineer, Coast Port and Estuary of Water Modelling, Bangladesh mds@iwmbd.org \\ ${ }^{4}$ Director, Coast Port and Estuary Management Division, Institute of Water Modelling, Bangladesh
}

\begin{abstract}
The Khaprabhanga Chapalir Don River (Mohipur channel), an important navigation route, is situated in the Upazilla Kalapara under the administrative district of Patuakhali. The sea going engine boats used to take shelter in this river during cyclone. The river has been experiencing siltation over the years. Boat cannot enter from Rabnabad and Andarmanik Channel to the Mohipur channel during the ebb tide. A comprehensive mathematical modelling study has been carried out to assess the capital dredging volume, resiltation rate, maintenance dredging, and dredge spoil locations. In the existing condition the navigation depth in the channel varies from $1.25 \mathrm{~m}$ to $2.00 \mathrm{~m}$ in the western stretch and in the eastern it is $0.50 \mathrm{~m}$ to $1.25 \mathrm{~m}$, which implies $4.00 \mathrm{~m}$ dredging is required to improve the navigability of the channel for movement of ships and engine boats. Model result shows that, for option-2 tidal flow/prism in the channel is increased by $21 \%$ during high tide compared to existing condition which indicates sustainable deeper channel compared to present condition. Navigable depth $3.60 \mathrm{~m}$ to $4.60 \mathrm{~m}$ can be achieved in this option. The capital dredging is about 3.40 million $\mathrm{m} 3$ and re-siltation rate is the least compared to the other options. However, the annual maintenance dredging is about $60 \%$ of the capital dredging. If high tide followed then maintenance dredging may be required after 6 months.
\end{abstract}

Keywords: - Navigability, Capital and Maintenance Dredging, Dredged Volume, Tidal prism, Siltation.

\section{INTRODUCTION}

The Khaprabhanga Chapalir Don River (Mohipur channel), river plays an important role on sea and river borne trade and socio-economic activities. The sea going engine boats used to take shelter in this river during cyclone. The river has been experiencing siltation over the years and navigability of the river has become very poor. Boat cannot enter from Rabnabad and Andarmanik Channel to the Mohipur channel during the ebb tide. The total study area is about 15000 ha. This river is one of the main drainage routes of the Polder 48 and 47. In view of the above a project has been undertaken by Bangladesh Water Development Board to dredge $24.00 \mathrm{~km}$ of the Mohipur channel by dredger. The study area is shown in the Fig 1.The main objectives of the feasibility study are:

- Planning and design of effective dredging alignment

- Assessment of capital and maintenance dredging volume

- Selection of suitable location for disposal of dredged spoil.

\section{METHODOLOGY}

The overall methodology is to define a base line condition and assessment of hydro-morphological condition with the aid of data and numerical modelling. In this study the existing Bay of Bengal model has been updated with the recently surveyed hydro-morphological data and latest satellite imagery. These available models updated using primary and secondary data. The secondary data collected from various sources. The primary data collected under this study. The updated model has been used for this study. IWM maintains Bay of Bengal Model (BoB) for simulation of hydrodynamic condition, morphology, salinity, wave, storm surge \& Tsunami. The updated model domain extends from Chandpur on the Lower Meghna river in the north to about 160 Latitude in the Bay of Bengal in the south. The mathematical modelling tool applied in this study is MIKE 21 FM (Flexible Mesh), a two dimensional modelling system of DHI Water Environment•Health based on flexible mesh approach. In this study Hydrodynamic Module and Mud Transport Module have been used in simultaneously for hydro-morphological investigation around the study area. The two dimensional (2-D) flexible mesh model (MIKE21 FM) has been applied to produce the existing water depth, water flow, water level and current speed of the river. The Morphological model has been used to predict the existing siltation and erosion pattern in the river. 


\subsection{Hydrodynamic Model}

\section{ILLUSTRATION}

In this study the existing Bay of Bengal model has been updated with the recently surveyed hydromorphological data and latest satellite imagery. The updated model domain extends from Chandpur on the Lower Meghna River in the north to about $16^{0}$ Latitude in the Bay of Bengal in the south. The coverage of the numerical model is shown in Fig 2. There are two open boundaries in the model, one is in the Lower Meghna River at Chandpur (northern boundary) and another one is in the Bay of Bengal (southern boundary). Predicted tide has been used in the southern boundary and observed water level at Chandpur BIWTA Station has been used in the northern boundary.

The riverbank alignment (land boundary) in the northern part of the model has been updated on the basis of the mosaic of IRS P6 LISS III satellite image 2008 provided by EDP. The model applies PWD datum, which is equivalent to $0.46 \mathrm{~m} \mathrm{SoB}$. The southern part of the Bay of Bengal is quite deep and the maximum depth along the southern open boundary is more than 3,000 meter. The computational grid or mesh size decreases (or the resolution increases) towards coastlines and Islands. Inter-tidal areas are flooded and dried during a tidal cycle, both in nature and in the model. Model has been upgraded within the Mohipur channel with the recent bathymetric data in 2010 .

\subsection{Sediment Transport Model}

The cohesive sediment transport module is coupled to the hydrodynamic module and they run in parallel. The governing equation for sediment transport is solved on the same mesh and applies information on water levels and currents from the hydrodynamic module to calculate the sediment transport. One layer describes the sea bed in the sediment transport model. In the upstream boundary on the Lower Meghna River, suspended sediment concentration time-series has been applied based on past measurements. Zero sediment concentration has been assumed at the south boundary. Initial sediment concentration in the Meghna Estuary is also based on the field measurement and MES measurement.

\subsection{Calibration of Model}

The updated and upgraded two-dimensional hydrodynamic model of the Bay of Bengal has been calibrated against water level, water flow at different locations comparing the model results with field measurement to make the model performance to a satisfactory level. The model results have also been examined with other set of data of different year and location compared to the data used in the calibration to validate the model. The validation has been made only with the available data for a recent year. Locations of water level and flow calibration areas is shown in Fig 3 and some calibration plots of flow and water level have been presented in Fig 4 and Fig 5 respectively.

\subsection{Potential Options of Dredging:}

Based on bathymetric data, tidal characteristics and requirement of navigability of the river Khprabanga four potential options have been considered in the study for capital dredging with the aim to improve the navigability of the river, reduce the drainage congestions and to develop harbor for sea going vessels and boats. The details of the potential options are described in Table 1.

\subsection{Effectiveness of Dredging Options:}

A tidal meeting zone is observed at $15.00 \mathrm{~km}$ from the western end of the channel, when tide approaches from the east and west and meets at this point. The navigation depth is very low and river condition is shallow and narrow. Efforts have been made to assess the effectiveness of four potential options to select the best suited option for improvement of navigation and drainage conditions.

In designing the navigation channel the main elements are the channel alignment, width, depth and the size and shape of manoeuvring spaces. Design channel width is defined as the width measured at the bottom of the side slopes on side of the channel at the design depth. Design section of navigational channel of the Mohipur channel has shown in Fig 6.For 4 meter draft ship and 10m width of the beam the design width of the navigation channel is considered $30 \mathrm{~m}, 60 \mathrm{~m}$ width for only $5 \mathrm{~km}$ at the western stretch of the channel for allowing higher draft ship to the fish market. It is assumed that the navigability of the river for ship movement is required for 24 hours operation. In the existing condition the navigation depth in the channel varies from $1.25 \mathrm{~m}$ to $2.00 \mathrm{~m}$ in the western stretch and in the eastern stretch available navigation depth is $0.50 \mathrm{~m}$ to $1.25 \mathrm{~m}$, which implies dredging is required to improve the navigability of the channel for movement of ships.

Fig 7, Fig 8 and Fig 9, Fig 10 shows the available navigation depth in the existing condition and Option-2 respectively. In the existing condition the navigation depth in the channel varies from $1.25 \mathrm{~m}$ to $2 \mathrm{~m}$ in the western stretch of the river and in the eastern stretch available navigation depth is $0.50 \mathrm{~m}$ to $1.25 \mathrm{~m}$, which 
implies dredging is required to improve the navigability of the channel for movement of ships and engine boats. Simulations of dredging of the channel along the existing alignment for all options have been carried out to find out the increase of navigation depth and re-siltation rate. For option -1 navigation depth is increased from 2.60 to $3.60 \mathrm{~m}$ in the channel but required navigable depth $(4.00 \mathrm{~m})$ is not achieved. Re-siltation rate is higher. Model result shows that the option-1 is not suitable to improve navigability of the river. In case of option-2 model result shows that tidal flow/prism in the channel is increased by $21 \%$ during high tide compared to existing condition which indicates sustainable deeper channel compared to present condition. Navigable depth 3.60 to $4.60 \mathrm{~m}$ can be achieved in this option. The capital dredging is about 3.40 million $\mathrm{m} 3$ and re-siltation rate is the least compared to the other options. However, the annual maintenance dredging is about $60 \%$ of the capital dredging. Under Option-2, the required navigation depth of $4.00 \mathrm{~m}$ is feasible to maintain operation of ship movement round the clock if the river is dredged and maintained after 3 months. The average tidal range of the channel is about $2 \mathrm{~m}$. If high tide followed then maintenance dredging may be required after 6 months. Capital dredging is reduced in Option -3 but required navigable depth is not sustained along the whole channel for 24 hours operation of fish port. Tidal prism is increased about $18 \%$, which would not able to sustain the deeper channel like option-2 also re-siltation rate is quite high, which is $69 \%$ in a year. The required navigation depth is achieved in the Option-4 along the deeper channel of the river except at the tidal meeting zone. Since required navigation depth is not achieved at the tidal meeting zone it would restrict the ship movement in the eastern part of the channel. Table 2 shows the tidal prism, average tidal volume in one tidal cycle, and Table 3 shows the Capital \& Annual Maintenance dredging volume and different options.

\section{TABLES AND FigURES}

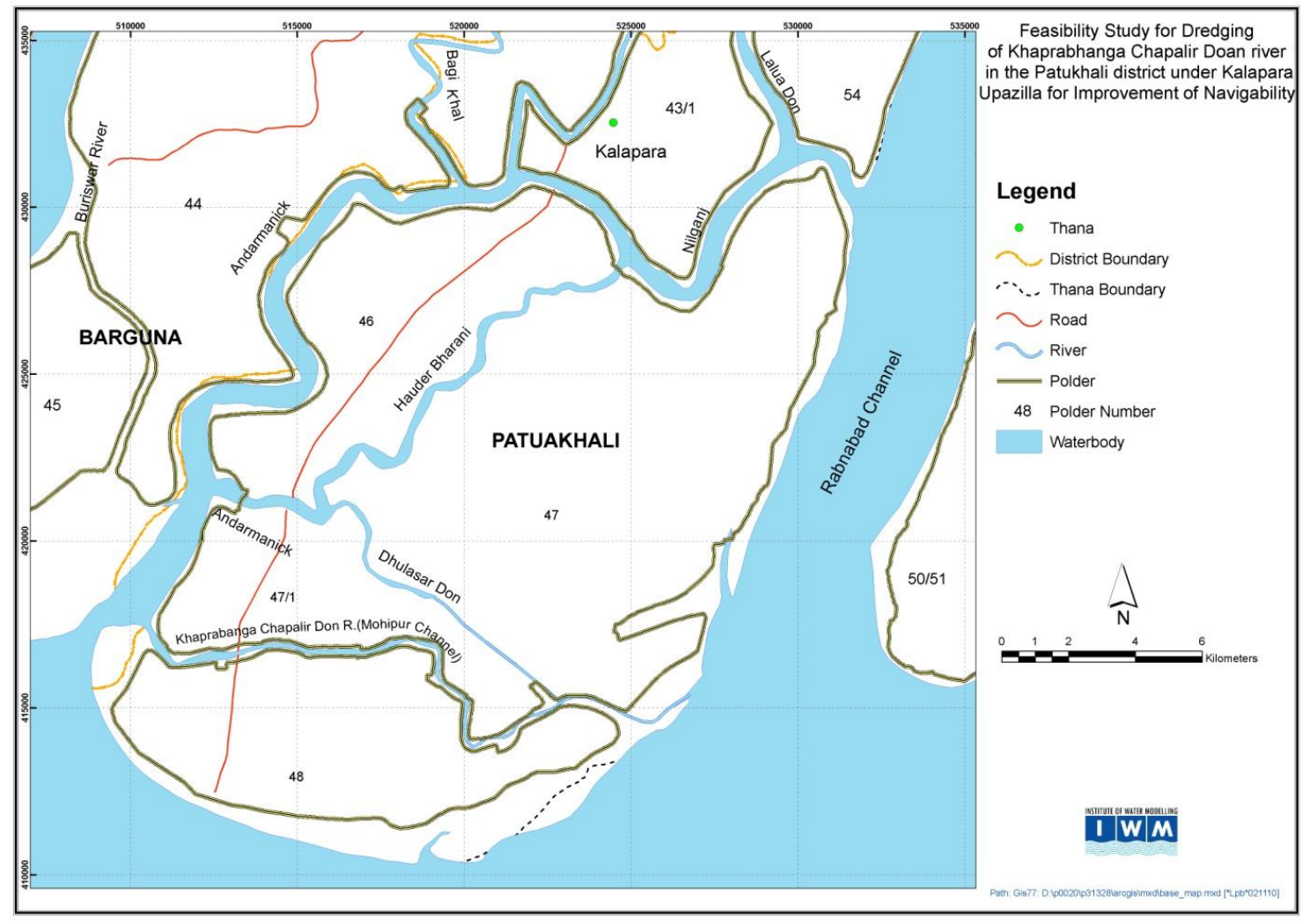

Fig 1: Map Showing the Study Area 
Feasibility Study for Dredging of Khaprabhanga Chapalir Don River in Patuakhali District for Improvement of Navigability

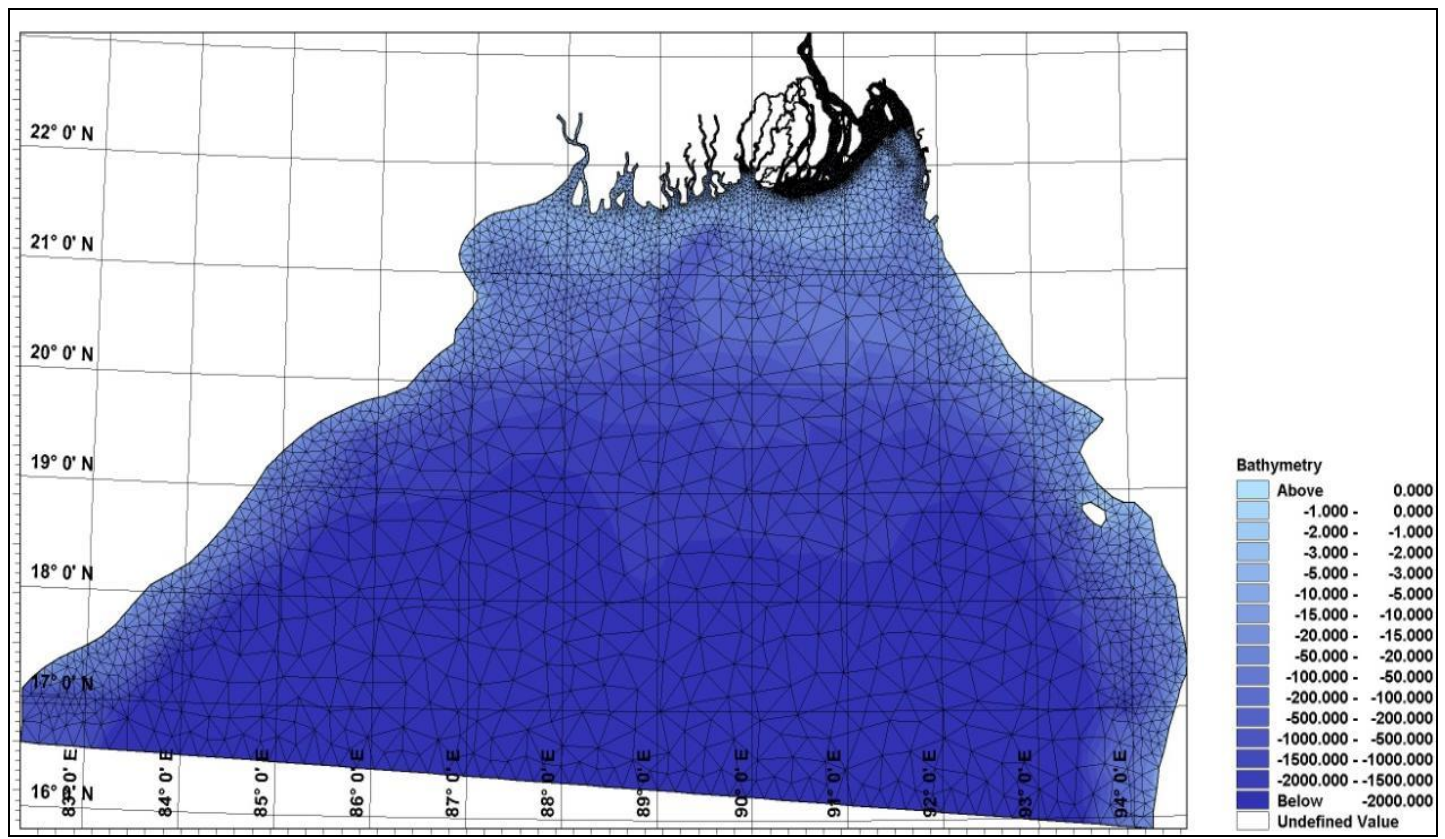

Fig 2: Bathymetry of the Bay of Bengal Model with flexible triangular computational mesh

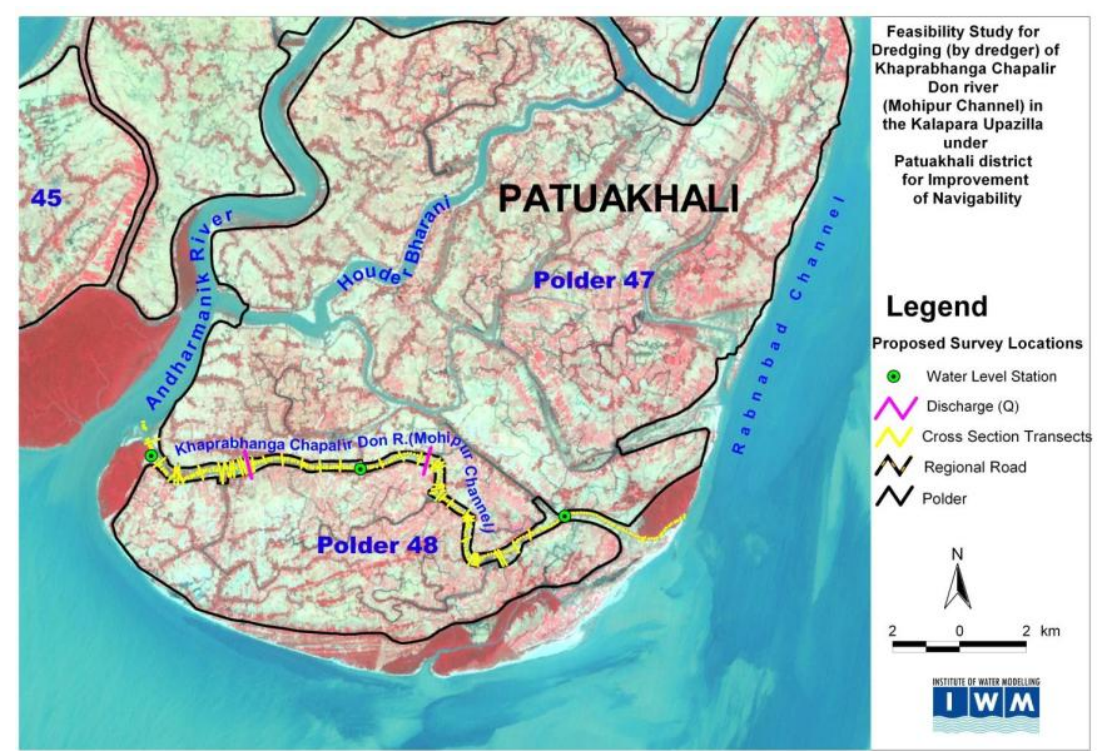

Fig 3: Field measurement locations
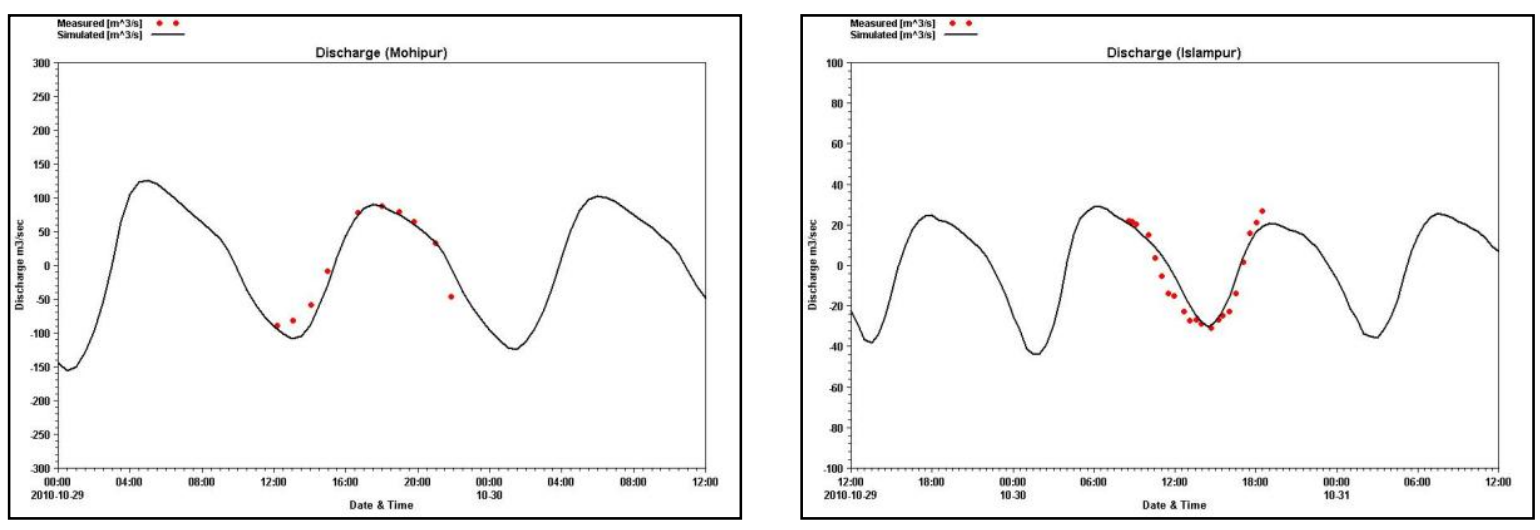

Fig 4: Water Flow Calibration at Mohipur and Islampur 
Feasibility Study for Dredging of Khaprabhanga Chapalir Don River in Patuakhali District for Improvement of Navigability
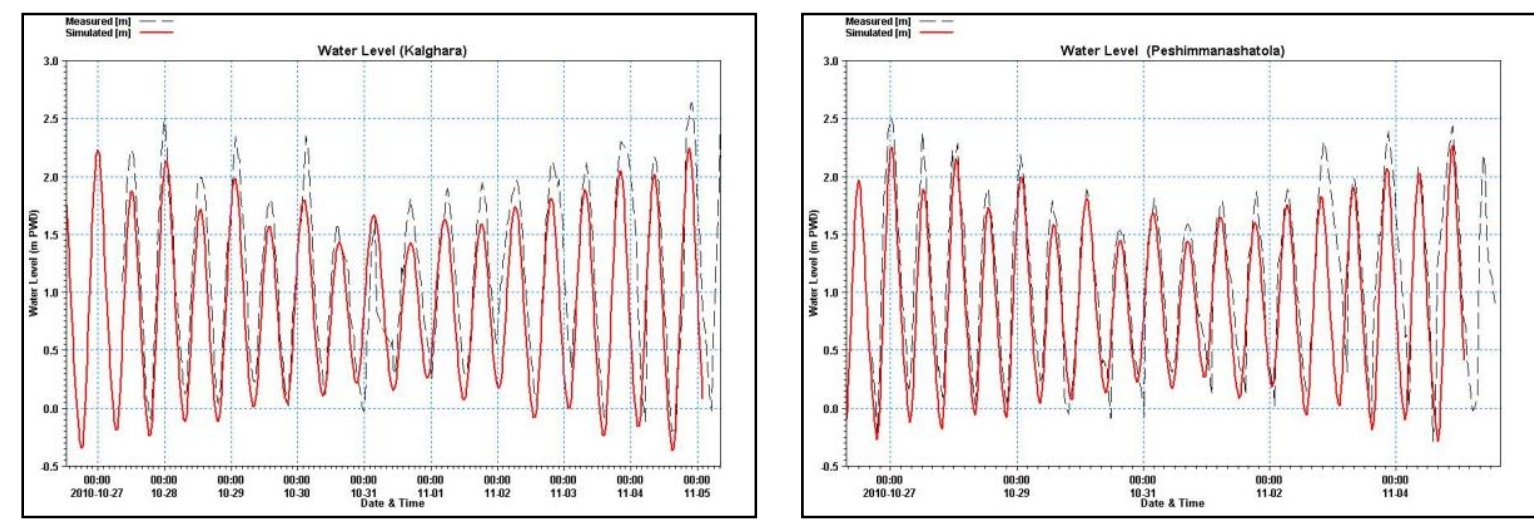

Fig 5: Water level calibration at Kalghara and Peshimmanashtola.

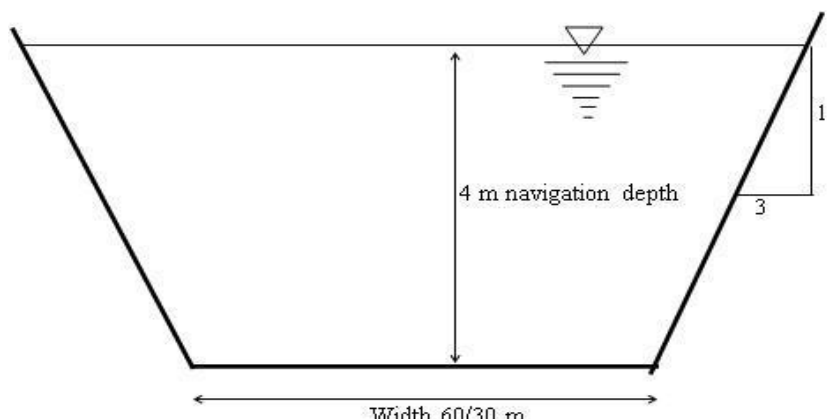

Fig 6: Design section of navigational channel of the Mohipur channel

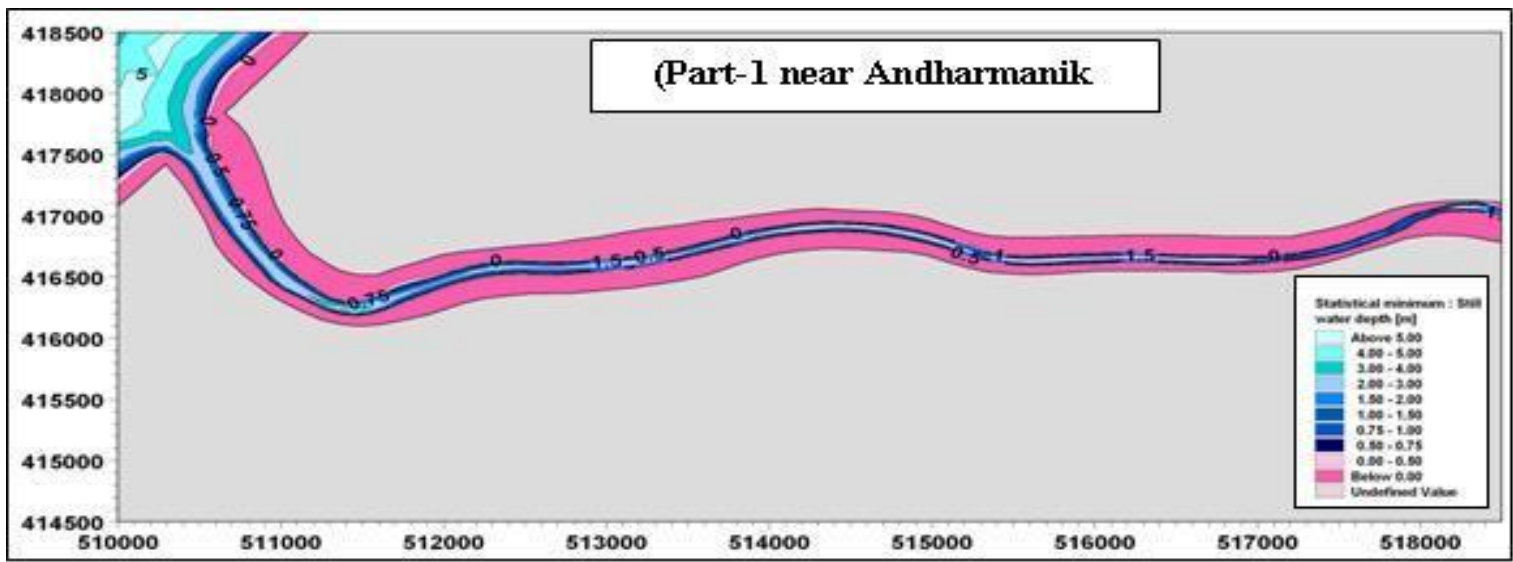

Fig 7: Navigation Water Depth for Base Condition

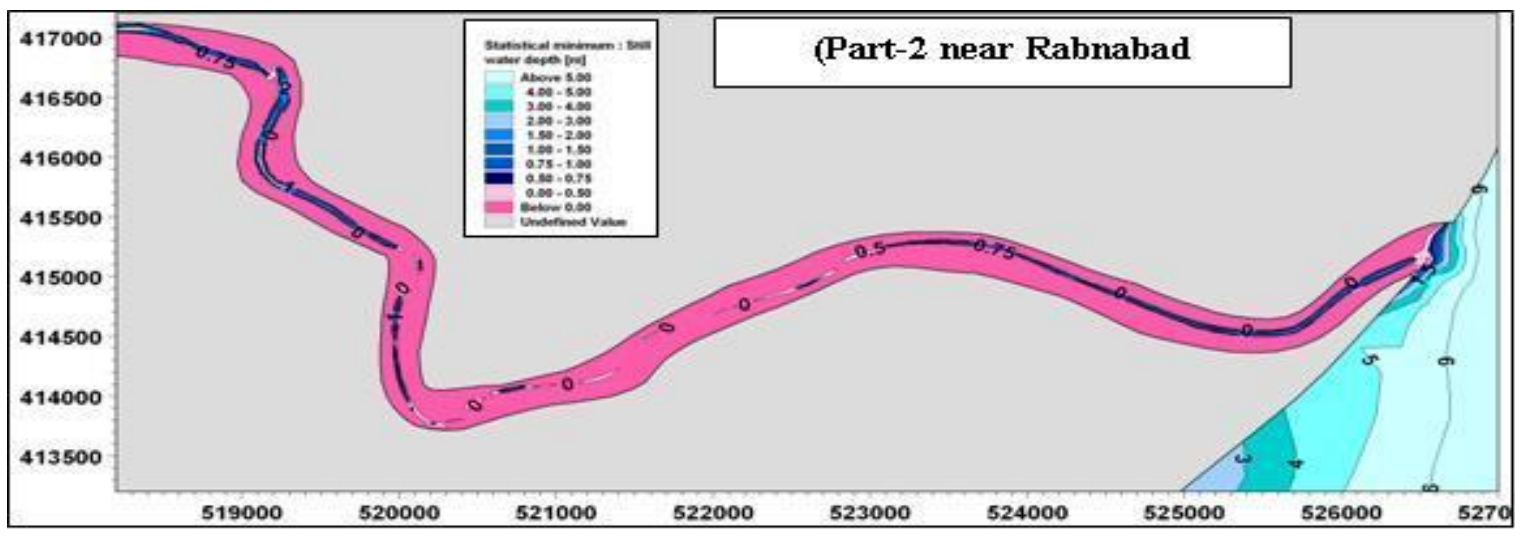

Fig 8: Navigation Water Depth for Base Condition 
Feasibility Study for Dredging of Khaprabhanga Chapalir Don River in Patuakhali District for Improvement of Navigability
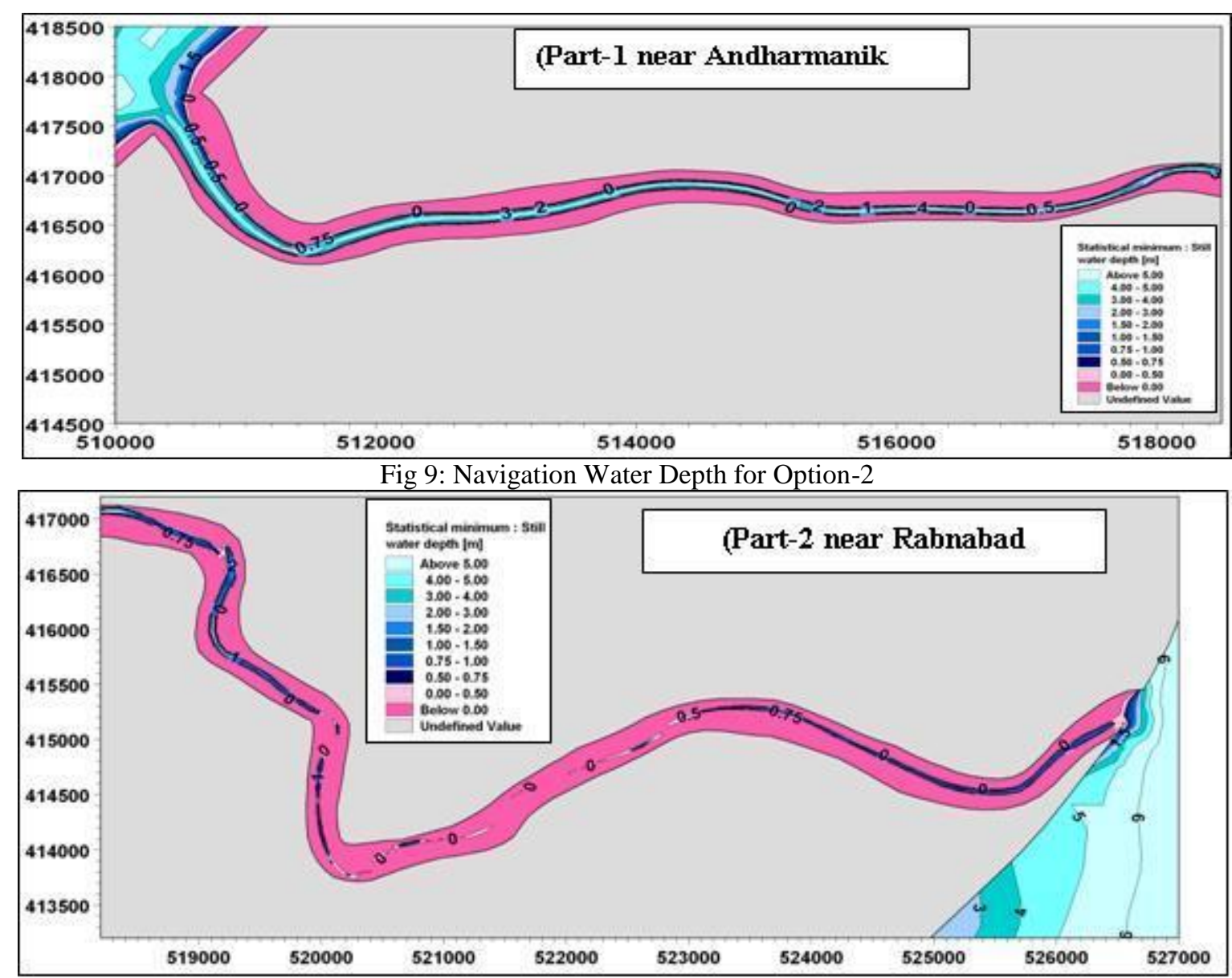

Fig 10: Navigation Water Depth for Option-2

Table 1: Description of four different options

\begin{tabular}{|c|c|c|c|c|c|}
\hline Options & $\begin{array}{c}\text { Chainage } \\
\text { (Mohipur } \\
\text { West to } \\
\text { East) }\end{array}$ & $\begin{array}{c}\text { Dredging } \\
\text { Length } \\
{[\mathbf{k m}]}\end{array}$ & $\begin{array}{c}\text { Dredging } \\
\text { Width } \\
{[\mathbf{m}]}\end{array}$ & $\begin{array}{c}\text { Dredged } \\
\text { River Bed } \\
\text { Level } \\
\text { [m, PWD] }\end{array}$ & Slope \\
\hline Option-1 & $0-5 \mathrm{~km}$ & $5 \mathrm{~km}$ & 60 & -4.0 & $1: 3$ \\
\cline { 2 - 6 } & $5-24 \mathrm{~km}$ & $19 \mathrm{~km}$ & 30 & -4.0 & $1: 3$ \\
\hline \multirow{2}{*}{ Option-2 } & $0-5 \mathrm{~km}$ & $5 \mathrm{~km}$ & 60 & -5.0 & $1: 3$ \\
\cline { 2 - 6 } & $5-24 \mathrm{~km}$ & $19 \mathrm{~km}$ & 30 & -5.0 & $1: 3$ \\
\hline \multirow{2}{*}{ Option-3 } & $0-5 \mathrm{~km}$ & $5 \mathrm{~km}$ & 60 & -4.0 & $1: 3$ \\
\cline { 2 - 6 } Option-4 & $5-24 \mathrm{~km}$ & $19 \mathrm{~km}$ & 30 & -5.0 & $1: 3$ \\
\cline { 2 - 6 } & $0-5 \mathrm{~km}$ & $5 \mathrm{~km}$ & 60 & -5.0 & $1: 3$ \\
\cline { 2 - 6 } & $5-15 \mathrm{~km}$ & $10 \mathrm{~km}$ & 30 & -5.0 & $1: 3$ \\
\cline { 2 - 6 } & $19-24 \mathrm{~km}$ & $4 \mathrm{~km}$ & 30 & -4.0 & $1: 3$ \\
\hline \multirow{2}{*}{} & $5 \mathrm{~km}$ & 30 & -5.0 & $1: 3$ \\
\hline
\end{tabular}

Table 2: Description of Tidal Prism for Base and four different options

\begin{tabular}{|c|c|c|}
\hline Scenario & $\begin{array}{c}\text { Tidal } \\
\text { Prism }\left(\mathbf{M m}^{\mathbf{3}}\right)\end{array}$ & \% increase \\
\hline Base & 7.17 & - \\
\hline Option-1 & 8.29 & 15.62 \\
\hline Option-2 & $\mathbf{8 . 6 9}$ & $\mathbf{2 1 . 2 0}$ \\
\hline Option-3 & 8.44 & 17.71 \\
\hline Option-4 & 8.40 & 17.15 \\
\hline
\end{tabular}


Table 3: Capital and Annual Maintenance Dredging Volume:

\begin{tabular}{|c|c|c|c|c|c|}
\hline \multirow{3}{*}{ Event } & \multirow{3}{*}{$\begin{array}{c}\text { Capital } \\
\text { Dredging }\left(\mathbf{M m}^{3}\right)\end{array}$} & \multicolumn{3}{|c|}{ Backfilling $\left(\mathrm{Mm}^{3}\right)$} & \multirow{3}{*}{$\begin{array}{c}\% \text { of } \\
\text { Backfilling } \\
\text { Rate } \\
\text { (One Year) }\end{array}$} \\
\hline & & Dry & Monsoon & Annual & \\
\hline & & $\begin{array}{l}\text { ( after } 6 \\
\text { month) }\end{array}$ & $\begin{array}{c}\text { ( after } 6 \\
\text { month) }\end{array}$ & $\begin{array}{l}\text { Maintenance } \\
\text { Dredging }\end{array}$ & \\
\hline Option-1 & 2.27 & 0.9 & 0.76 & 1.66 & 73 \\
\hline Option-2 & 3.4 & 1.2 & 0.85 & 2.05 & 60 \\
\hline Option-3 & 2.77 & 1.1 & 0.8 & 1.9 & 69 \\
\hline Option-4 & 3.05 & 1.12 & 0.81 & 1.93 & 63 \\
\hline
\end{tabular}

IV.

CONCLUSION

The Khaprabhanga Chapalir Don River is an important navigation route in the Patuakhali district and main drainage channel of the polders $47 / 4$ and 48 . The sea going engine boats used to take shelter in this river during cyclone. The river has been experiencing huge siltation over the years and navigability of the river has become inadequate for $4 \mathrm{~m}$ draft vessel. The river plays an important role on river borne trade and socioeconomic activities of the area. Siltation caused deterioration of the navigability of the river that leads to declining of trade and socio-economic activities of the area. A comprehensive survey, hydrological and morphological investigations have been carried out to find out the causes of siltation and potential solutions of improvement of the navigability. There is a strong tidal influence in the river. Initially tide enters into Mohipur Channel from the Andar Manik River and flows to the east since tide arrives faster at the western channel compared to the eastern side of the channel. A tidal meeting zone is observed near the eastern zone when tide approaches from the east and west and meets at this point. The navigation depth is very low and river condition is shallow and narrow at this location. Four potentials options have been investigated using state of art mathematical modelling technology under the present study. The whole $24.00 \mathrm{~km}$ of the Khaprabhanga Chapalir Don River is suggested to dredge at $-5.00 \mathrm{mPWD}$ (Option -2) to improve navigability for enhancing river borne trade, development of harbor, improvement of drainage of the polder 47 and 48 and socio-economic activities. The option- 2 is technically feasible, economically viable and environment friendly.

\section{ACKNOWLEDGEMENTS}

The authors express their gratitude to Institute of Water Modelling (IWM) and Bangladesh Water Development Board (BWDB) for the support to use their joint study findings in the paper.

\section{REFERENCES}

[1] AIT, Nguten Huong Thuy Phan (1998), "Field Application of 2D Morphological Modelling for Estuarine and Coastal Areas"

[2] DHV Consultants BV (2001). Hydro-morphological Dynamics of the Meghna Estuary (MES II)

[3] IWM (2010), Updating of Hydrodynamic \& Morphological Models to Investigate Land Accretion \& Erosion in the Estuary Development Program (EDP) Area.

[4] IWM (2009), "Survey and Modelling Study of Sandwip-Urirchar-Noakhali Cross-Dam(s)", Final Report submitted to Char Development and Settlement Project-III (CDSP-III) by IWM.

[5] O' Brien, M.P. (1969). "Equilibrium Flow Areas of Inlets on Sandy Coast", Journal of the Water Ways and Harbours, DIV, Proc. ASCE.

[6] O' Conor, B.A., Nicholson, J. (1989), "Modelling Changes in Coastal Morphology", Proc. A.S.C.E. Int. Symposium on Sediment Transport Modelling, S.Y. Wang (Ed.), pp. 160165.

[7] SWMC (2001), "Two-dimensional General Model of the Meghna Estuary", Second Update Report, submitted to Meghna Estuary Study (MES) by Surface Water Modelling Center.

[8] Wallingford (1984), "Mathematical model Studies of Schemes Designed to Improve Depth at the Port", Port of Chalna Bangladesh, April 1984. 